\title{
De l'Estudi General a la Universitat de les Illes Balears
}

\section{From the Estudi General to the University of the Balearic Islands}

\begin{abstract}
Resum: L'Estudi General de la Ciutat de Mallorca, creat el 1483, concedia graus en teologia, filosofia $\mathrm{i}$ arts, vàlids únicament en el territori de la monarquia hispànica. Des de mitjan segle XVI va haver d'afrontar la competència del col legi dels jesuïtes. Per superar aquesta pugna sol licità i obtingué (1673) que el papat reconegués las validesa dels seus títols a tota la cristiandat. Les dificultats econòmiques retardaren el funcionament d'aquesta universitat fins el 1691. Rebé el nom de Universitat Lul liana de Mallorca. El 1772 passà a denominar-se Universitat Literària de Mallorca. El 1842 se suprimí definitivament. A Mallorca no hi tornà haver estudis universitaris fins a 1967, i el 1978 es creà la Universitat de les Illes Balears.
\end{abstract}

Paraules clau: Universitat, Mallorca, Illes Balears, lul lisme

Abstract: The Estudi General de la Ciutat de Mallorca was an institution founded in Palma in 1483 which awarded degrees in theology, philosophy and the arts, valid only in the kingdoms of the Spanish monarchy. From the mid 16th century, it faced competition from a Jesuit college. To win this battle, it asked the Pope to recognize the validity of its qualifications throughout the whole of the Christian world, and this request was granted in 1673. Due to financial difficulties, the university-known as the Universitat Lul liana de Mallorca or Lullian University of Mallorca-did not start operating until 1691 and, in 1772, its name was changed to the Universitat Literària de Mallorca (Mallorca Literary University). The institution was abolished in 1842 and no university studies were available in Mallorca until 1967, with the ensuing creation of the Universitat de les Illes Balears (University of the Balearic Islands) in 1978.

Key words: University, Majorca, Balearic Islands, lullism 


\section{Els precedents. Una llarga etapa transitòria. L'Estudi General}

El 16 de desembre de 1697 un decret promulgat per Carles II va permetre legitimar les constitucions i estatuts de la Universitas Majoricensis Luliana, que deuria estar en funcionament des de feia més de Dos-cents anys, en execució del privilegi atorgat a Còrdova, per Ferran el Catòlic, el 30 d'agost de1483 (Santamaría 1984: 87-96), concretament des de feia docents catorze anys. D'aquesta manera el projecte d'instaurar una Universitat a la Ciutat de Mallorca va arribar finalment a port després d'una incerta i desigual trajectòria, durant la que se superaren etapes competitives, d'escepticisme, d'atonia i de manca de recursos. La fundació universitària mallorquina va suposar un llarg i lent procés en el que la Universitat mallorquina va viure sense llicència pontifícia i sense una regulació estatutària, sense constitucions a més de amb greus dificultats econòmiques. L'esmentat decret reial, publicat el 1698, no va partir de zero, més be el que va fer va ser legalitzar a nivell europeu estudis que ja de fet s'estaven desenvolupant en part i de manera intermitent, malgrat que sense validesa acadèmica oficial només en el regne de Mallorca. La Universitat mallorquina va experimentar una llarga fase transitòria, superior als dos segles, amb molts d'alts i baixos.

Els seus precedents foren les càtedres lul lianes fundades a finals del segle Xv per dues dones riques, que actuaren de mecenes: Beatriu de Pinós a 1477 (Santamaría 1976: 79-85) i Agnès de Quint el 1481 (Lladó 1973: 33-36 i Santamaría 1984: 206-209). Beatriu de Pinós donà els seus bens al regne de Mallorca pel manteniment d'una escola, la missió de la qual havia de ser fomentar la docència i la investigació sobre Ramon Llull. Gràcies a la fundació d’Agnès de Quint, que assignà una renda per a la dotació d'una càtedra lul liana, vingué a Mallorca, Pere Daguí, un català, destacat lul lista, les lliçons teològiques del qual tingueren un gran èxit i foren motiu d'importants controvèrsies entre tomistes, escotistes i lul listes. Aquestes tensions doctrinals varen contribuir a la promoció del privilegi fundacional atorgat a Còrdova el 30 d'agost de 1483 per Ferran el Catòlic, que autoritzà la creació d'un Estudi General a la Ciutat de Mallorca.

Aquest privilegi, concedit a instància dels jurats de la ciutat de Mallorca (Lladó 1973: 254) per a que els naturals no haguessin de desplaçar-se a estudiar i graduar-se a la península, va ser només una llicència del monarca per crear a la capital mallorquina un Estudi General, que havia de tenir com a model, la estructura i els privilegis de l'Estudi General de Lleida de 1300. Les càtedres lul lianes preexistents es varen integrar en aquest Estudi General. El privilegi atorgat per Ferran el Catòlic només creà un Estudi General damunt el paper, no suposà la seva immediata posada en marxa. La no posada en total funcionament de l'Estudi General implicà que el privilegi fundacional, que facultava la erecció d'aquell, hagués de ser sol licitat i reiterat diverses vegades a llarg del segle XVI, a instàncies dels representants del regne. La manca de llicència apostòlica per poder concedir graus vàlids fora les fronteres del regne va ser un problema que també hi va que haver d'afrontar. Durant el segle XVI a l'Estudi General s'impartí docència fonamentalment sobre lul lisme. La precarietat financera va ser un problema estructural que es va fer present des del primer moment de la fundació d'aquest Estudi.

SCRIPTA, Revista internacional de literatura i cultura medieval i moderna, núm. 15 / juny 2020 / pp. 187 - 200 ISSN: 2340-4841 · doi:/ SCRIPTA.15.17568 
La primera ratificació del privilegi fundacional va tenir lloc durant el regnat del mateix Rei Catòlic, qui ho va confirmar a Saragossa el 1503. Malgrat tot, abans de finalitzar el segle xv ja s'impartien ensenyaments d'arts i humanitats subvencionats per l'administració, a més de les càtedres de lul lisme dotades per Beatriu de Pinós i Agnès de Quint. El 1500 hi havia «en la present ciutat Scoles de Arts e de Humanitats» (Santamaría 1983: 245). Aquest mateix any, el Gran i General Consell va atorgar poders als jurats per adquirir una casa per ampliar les escoles «e que hi sia posada una pedra de Santanyí ab les armes de la ciutat» i afegir la dotació d'una lectoria de teologia i un altre de lleis «per que los fills de la terra se puguen habilitar per que no hagen de anar fore lo regne a maior despesa».

Noves confirmacions tingueren lloc durant els regnats dels primers Àustries. Posar en marxa un centre universitari no va ser fàcil. El Gran i General Consell, després de les desfetes causades pels agermanats a la tercera dècada del Cinc-cents - «aquesta Universitat va molt endarrerida a causa quels drets han presa gran disminució per la germania... que de gran part no abasten a pagar los gastos ordinaris»-, va promoure la concessió d'un nou privilegi confirmatori del fundacional: aquest va ser el privilegi atorgat per l'emperador Carles a Sevilla el 1526. Durant gran part del segle XvI, les úniques càtedres organitzades foren les de lul lisme. A les dues ja creades, s'hi afegiren dues més de teologia, promogudes per la ciutat i sense remuneració. Se donaven classes de gramàtica, superades les quals, després se procedia a l'estudi de la filosofia lul liana i després a la teologia i així se completava tot un cicle d'estudis lul lians. L'activitat dels catedràtics lul lians era relativament aillada, però comptà amb el beneplàcit de Felip II, que va ser un devotíssim lul lià. El 1595 s'havien incoat les gestions per aconseguir la canonització de Ramon Llull. Però els jurats de Mallorca, malgrat que compartien la defensa del lul lisme, més pragmàtics se feien ressò de la necessitat de disposar d'uns estudis universitaris complets a l'illa, que contribuïssin a la formació de professionals del dret i de la medicina, que poguessin prestar serveis a la societat illenca (Barceló i Urgell 2002: 157-192).

El 31 de gener de 1585, el Gran i General Consell se va replantejar la conveniència d'aplicar el privilegi de fundació d'un Estudi General que «may era posat en execució per no trobarse en Mallorca tanta abundància de bons doctors y mestres ni tanta afectió i còpia de estudiants» (Santamaría 1984 : 142-145). A més les ordes religioses, com els franciscans i els jesuítes havien començat a muntar aules d'Arts i de Teologia «a les quals acuden molts estudiants axi de la ciutat com de la part forana». Els jesuítes immediatament després de la seva vinguda a Mallorca el 1561, començaren a impartir estudis d'Arts. L'afluència i l'augment del número d'alumnes provocà que les aules primigènies no tinguessin suficient cabuda i que l'orde hagués d'adquirir cases veïnades per ampliar el lloc d'impartir docència. Les ordes religioses tenien un mètode docent comú a tota la cristiandat, que resultava atraient per els estudiants. El 1573 tingué lloc la primera elecció d'un catedràtic de cirurgia en la persona de Joan Gual. El 1597, els jurats acordaren crear un altre càtedra d'Anatomia. Malgrat això els estudis de Medicina funcionaren de manera irregular i discontinua fins a finals del segle xviI. L'Estudi General es centrà en els estudis d'Arts i de Teologia, mentre els estudis de Dret i de Medicina funcionaren poc i de fet les càtedres varen ser efímeres. Durant el segle XVI la dotació de càtedres fou lenta i minsa.

SCRIPTA, Revista internacional de literatura i cultura medieval i moderna, núm. 15 / juny 2020 / pp. 187 - 200 ISSN: 2340-4841 · doi:/ SCRIPTA.15.17568 
Abans de la conclusió del segle, el 1597, Felip II a sol licitud dels síndics del regne de Mallorca, va concedir a l'Escorial un nou privilegi que ratificava els de 1483, 1503 i 1526 sobre la erecció d'un Estudi General a la Ciutat de Mallorca (Lladó 1973: 255-256). Els representants del regne de Mallorca també havien instat al papat a confirmar els privilegis facultatius reials i a atorgar una llicència apostòlica per facultar a l'Estudi General de Mallorca per a concedir graus «com se fa en altres Universitats». Aquest any varen ser creades cinc càtedres dotades en sis-centes lliures. Aquestes foren per les facultats d'Arts i de Teologia. Però aquest projecte d'erecció universitari no prosperà per la forta oposició dels dominics a Roma. El lul lisme deixà de ser una doctrina protegida després de la mort de Felip II. Les lluites entre lul listes i antilul listes s’incrementaren en el segle XVII.

La tònica del segle xvi es mantingué durant gran part del segle XVII, amb un ritme intermitent, en el que se presentaven projectes que no prosperaren, o que només ho feren a mitges, a causa en bona part de la oposició dels dominics i de la manca de recursos. A partir de 1620 començà un període de fundació de càtedres. Diversos llegats particulars contribuïren a disminuir la precarietat econòmica de l'Estudi. El 1626 un mercader, Gabriel Riera, va dotar tres càtedres annexes de tomisme, a canvi de que els dominics deixessin de maniobrar contra la creació de la Universitat. Aquestes tres càtedres «las hagen de servir y llegir perpètuament religiosos de la orde del gloriós pare Sant Domingo» (Santamaría 1984: 276). L’orde de predicadors va donar validesa als títols tomistes. El maig de 1626 es va acordar la creació de totes les facultats de l'Estudi, incloent-hi les de Lleis i Medicina, però amb el mateix pressupost de 1597, és a dir, amb sis-centes lliures anuals. A partir d'aquí se troben les primeres càtedres estables de Dret i de Medicina. De Dret se crearen tres càtedres: una de lleis, una de cànons i un altre de Instituta (Planas 2011: 86-87). Els salaris dels professors de lleis i cànons corrien a càrrec de la ciutat i el de Instituta del col legi de la Mercaderia. Els juristes mallorquins formats a partir de llavors tingueren una certa competència, però no la mateixa altura intel lectual que el segle anterior i poc aportaren al món de la creació del dret (Planas 2011: 91). De Medicina se crearen altres tres càtedres, una de Prima, un altra de Vespres i una tercera de Curs. A elles s'afegí un altre d'Anatomia. La càtedra d'Anatomia que els jurats havien creat a finals del segle anterior i que hauria tingut una existència irregular, adquirí continuïtat des de 1626. També se va dotar una càtedra d'Arts.

El Gran i General Consell encomanà a una comissió assessora de doctors l'elaboració d'un nou esquema organitzatiu dels estudis universitaris que s'impartien a l'Estudi General. Però l'Estudi General va haver de continuar patint la competència de qualcunes ordes religioses, que varen fer quan pogueren per destorbar la posada en funcionament de la institució universitària. Franciscans i jesuïtes volien formar part de la futura Universitat a canvi de recolzar la seva erecció. L'any 1626, se'ls va ocórrer als jesuïtes sol licitar al rei la facultat de poder concedir graus de filosofia i de teologia. Per superar aquesta pugna, el regne de Mallorca sol licità i finalment obtingué que el papat reconegués en un breu la validesa dels seus títols a tota la cristiandat. Els jesuïtes renunciaren a conferir graus a canvi d'integrar-se a la futura Universitat. 


\section{El procés d'institucionalització en el darrer quart del segle XvII: La Universitat Lul liana i Literària}

El 24 d'abril de 1673, el papa Climent X, després de negociacions entre el bisbat de Mallorca i les ordes religioses, va expedir un breu que facultava la validesa universal dels títols atorgats per l'Estudi General de Mallorca i la seva transformació en Universitat -«in publicam Universitatem»-, amb competència per concedir títols de batxillers, llicenciats i doctors a aquells estudiants quer provessin els seus sabers, mèrits i capacitats (Miralles 1897-98: 187-188, Lladó 1973: 291-292 i Santamaría 1979: 43-47). Aquesta prerrogativa de la Santa Seu feia que a Europa hi hagués dos tipus d'universitats: les que expedien títols d'abast general, vàlids i acceptats arreu de tot el món cristià, i les que atorgaven una titulació que només era admesa dins el territori del regne al que pertanyia l'Estudi General corresponent.

El breu pontifici de 1673 fou possible gràcies al consens entre l'Estudi General, el bisbat i els col legis dels jesuites i franciscans. Aquests renunciaren a la concessió de graus a canvi de poder controlar determinades càtedres de la nova Universitat. Sol licitaven càtedres suaristes i escotistes per formar els seus religiosos i col lacionar graus universitaris. Aquesta nova Universitat estaria integrada per les facultats d'Arts i Filosofia, Teologia, Cànons i Lleis i altres Ciències. Aquesta Universitat si bé era una institució que comptava amb un llarg recorregut secular, era una institució que ja va néixer endarrerida. A partir de llavors se succeïren nomenaments, provisions i fundacions de càtedres (Santamaría 1979: 33 i 1984: 296-300). Entre 1673 i 1691 hi hagué intenses negociacions a la Cort de Carles II per poder oficialitzar degudament els privilegis universitaris. En aquests anys els professors romanien expectants. L'agost de 1673, la reina Mariana d'Àustria autoritzà el traspassament d'una partida de sis mil lliures durant tres anys del fons de la fortificació de la ciutat per a dotar càtedres universitàries, en virtut del breu concedit pel papat. La facultat de Medicina fou la més afavorida. Completaren el quadre les de Dret, Teologia, Arts i Filosofia i Retòrica. Malgrat tot això, la concurrència d'estudiants continuà essent limitada i les dificultats econòmiques retardaren el funcionament de la Universitat. Els estudiants mallorquins, en aquells anys, amb una universitat que existia més en la teoria que en la pràctica, solien anar a formar-se a la península, a València, a Catalunya o a Aragó, i inclús al sud de França i a Itàlia. Els dominics acabaren cedint respecte al projecte universitari, malgrat que se mantingueren inflexibles respecte a la seva oposició a la seva orientació pro-lul liana.

El 1691 se va constituir una comissió encarregada d'elaborar els nous estatuts de la Universitat. La formaren dos nobles -el marquès de Bellpuig i el comte de Montenegro- i dos eclesiàstics un canonge, Pere Joan Descatlar i un consultor del tribunal de la Inquisició, Bernardí Bauçà-. El llavors virrei de Mallorca, el marquès de Villatorcas va ser un decidit impulsor de la seva activitat (Juan Vidal 2019: 83). Altres foren el bisbe Pere d'Alagón, oncle del virrei, i el teòleg Pere Joan Descatlar, que el 1694 fou nomenat pel Gran i General Consell síndic davant la Cort i que va ser qui aconseguí que Carles II sancionás definitivament les constitucions, estatuts i privilegis de la

SCRIPTA, Revista internacional de literatura i cultura medieval i moderna, núm. 15 / juny 2020 / pp. 187 - 200 ISSN: 2340-4841 · doi:/ SCRIPTA.15.17568 
Universitat. Els dominics s'oposaren a la fundació de la Universitat. El 7 de maig de 1693, els jurats i els síndics forans, en base al poder atorgat per el Gran i General Consell, aprovaren el projecte d'estatuts elaborat per la comissió, que el 6 d'octubre va ser aprovat per el Consell Suprem d'Aragó. El 16 d'octubre el rei Carles II promulgà els estatuts que foren impresos a Mallorca, al taller de Melchor Guasp, el 1698 amb el títol de «Constituciones, Estatutos y Privilegios de la Universidad Luliana del Reino de Mallorca». La comissió redactora tingué en compte el que era aplicable a finals del segle XVII dels Estatuts de la Universitat de Lleida de 1300, i dels Estatuts de la Universitat de Barcelona, impresos el 1596. El procés de desenvolupament universitari iniciat a Mallorca el 1483 culminà el 1697, quan se promulgaren els estatuts. Tingué lloc finalment la reconversió de l'Estudi General en Universitat. A cap altre Universitat, el procés instituidor va ser tan lent.

Els nous estatuts varen reglamentar tota la vida universitària mallorquina: els càrrecs, l'accés a la Universitat, els plans d'estudis, l'accés a les càtedres, els recursos econòmics... El bisbe de Mallorca, com a la Universitat de Barcelona, seria el canceller de la Universitat. El rector seria elegit pels jurats. Habitualment seria una dignitat eclesiàstica o qualque prebendat de la Seu. Se regularen també altres càrrecs com el secretari -que era el mateix que el de la ciutat i regne de Mallorca-, el prefecte d'estudis -que era un eclesiàstic graduat-, el clavari o tresorer, l'arxiver, el síndic i el bidell i les seves obligacions i responsabilitats, així també com el consell assessor del rector. Els nous estatuts varen quedar marcats dins de la ideologia de la Contrareforma. La Universitat havia de ser per a estudiants que poguessin demostrar ser bons cristians, dels que se requeria confessionalitat i professió de fe. Els estatuts preceptuaren el que era lícit i el que estava prohibit. En la nova Universitat varen imperar els estatuts de neteja de sang, a uns moments en els que la Inquisició havia emprés una forta activitat repressora contra la minoria xueta. S'exigí puresa de sang per ingressar i poder-se matricular, lo que deixà fora de la institució als xuetes (Cassanyes y Ramis 2014: 284-285).

Les constitucions regularen la fórmula d'accés a la Universitat, les classes, els exàmens i una potencial convalidació de títols amb altres trenta dues Universitats, entre les que s'inclogué inclús alguna americana. Arbitraren una fórmula d'accés per als alumnes d'Arts de Menorca amb un aval del vicari general d'aquella illa. El calendari acadèmic de classes començava el 20 d'octubre i durava sense interrupció fins el 30 de maig. Els estatuts regularen també les festes. Ramon Llull fou declarat patró de la Universitat, que agafà la denominació de Universitat Lul liana. Una denominació que no va ser accidental ni accessòria sinó que va voler definir la trajectòria intel lectual de la nova institució universitària. Va constituir el signe d'identitat de la Universitat mallorquina.

Les constitucions varen establir també la fórmula per a la obtenció de graus i l'accés a les càtedres, que es faria a partir de llavors per oposició. Aquestes càtedres podien ser perpètues o majors, $\mathrm{i}$ temporals o menors, i dotades a nivell públic o a títol particular per fundacions establertes pels seus patrons. S'estipularen les obligacions dels catedràtics, les seves hores de classe i les conclusions que havien de sustentar cada curs. El número de càtedres, malgrat que era variable, s'establí en principi

SCRIPTA, Revista internacional de literatura i cultura medieval i moderna, núm. 15 / juny 2020 / pp. 187 - 200 ISSN: 2340-4841 · doi:/ SCRIPTA.15.17568 
en quatre per cada opinió. Una de les principals novetats introduïdes per les noves constitucions va ser l'obligatorietat de cobrir totes les càtedres vacants -excepte aquelles annexes als convents o que tinguessin patrons sufraganis- per oposició. Des de 1626 les càtedres solien ser proveïdes per designació. Els jurats, els síndics clavaris de la part forana, i des de 1690 el rector elegien directament la persona que els semblava més adient per ocupar una càtedra vacant, sense que això hagués estat especialment espinós o problemàtic. El professorat es nodrí del personal procedent de les ordes religioses, excepte el de Medicina. Les càtedres a partir de llavors sofriren les pressions que exerciren per controlar-les les ordes, especialment jesuïtes, franciscans i dominics.

Els nous estatuts formularen i redefiniren els plans d'estudis. Les Facultats eren les d'Arts i Filosofia, Teologia, Cànons i Lleis i Medicina. Hi havia una precedència entre les Facultats, la primera era la de Teologia, a la que seguia Cànons i Lleis, després Medicina i finalment Arts i Filosofia. La preeminència de la Facultat de Teologia era deguda al millor futur que oferia la carrera eclesiàstica. Els recursos econòmics de la Universitat eren aportats per la hisenda de la ciutat, si bé alguns estudis eren atesos amb rendes del bisbat. S'estipularen els salaris dels catedràtics i demés oficials de la institució. Des de l'any 1693, la Universitat ja funcionà com a tal amb certa regularitat. Els estudis de Medicina s'impartien complets des de 1695 (Bestard 2008: 149). Aquell any s'agregaren a la Universitat, una sèrie de doctors que havien estudiat a les Universitats de Gandia i de Solsona. Malgrat tot, entre 1693 i 1697, període que abasta des de l'aprovació dels seus estatuts per el Gran i General Consell fins a la seva ratificació per part de Carles II, aquells varen ser utilitzats segons la conveniència de les autoritats: si era necessari observar-los per satisfer els seus objectius, no dubtaven en aplicar-los, en canvi si representaven un obstacle, s'escudaven en l'argument que encara no havien estat ratificats pel rei, per evitar-los (Cassanyes 2011: 203). La utilització dels estatuts segons interessos particulars serà una característica dels primers anys de la Universitat Lul liana i Literària.

Els començaments de la docència universitària no foren fàcils a causa de problemes de competències. Els dominics, partidaris del tomisme i rabiosament antilul listes, volien copar el poder universitari i no estaven disposats a consentir que la Universitat mallorquina fos una escola de lul lisme. Les Facultats d'Arts i Filosofia i sobretot les de Medicina i Teologia patiren greus convulsions a la dècada finisecular del Sis-cents (Cassanyes 2011: 193-204). La més destacada va tenir lloc el 6 de juny de 1699, quan es perpetrà un ultratge contra una estatueta de Ramon Llull, situada en el bací de recollida d'almoines de la Universitat, que va ser robada i no va poder ser trobat l'autor del furt. En el seu lloc s'hi va depositar un escrit que deia «inter hereticos locum». Dies després aparegueren fragments de l'esmentada estàtua, el que generà una autèntica commoció a la Universitat. (Lladó 1973: 258-262 i Cassanyes y Ramis 2012: 141-165). Es donà part d'aquest fet al virrei, al bisbe i als jurats. Es reuniren el claustre de la Universitat i el Gran i General Consell per aquest tema (Pérez Martínez 1985: 334-345). Uns estudiants tomistes foren detinguts i s'organitzaren actes de desgreuge.

SCRIPTA, Revista internacional de literatura i cultura medieval i moderna, núm. 15 / juny 2020 / pp. 187 - 200 ISSN: 2340-4841 · doi:/ SCRIPTA.15.17568 
Entre 1744 i 1749 exercí com a catedràtic de teologia escotista, el franciscà Juníper Serra, abans de partir cap a Amèrica. Els dominics varen ser privats de les seves càtedres el 1750 a rel d'incidents antilul lians (Pérez 1989: 333-341). L'any 1754 el Consell de Castella autoritzà la provisió de les càtedres de les que havien estat privats els dominics. Però els frares de Sant Domingo tornaren a elles el 1761 i a partir de llavors anaren agafant força. L'Ajuntament de Palma, el capítol de la Seu, la Universitat Lul liana i la Causa Pia Lul liana acordaren enviar un síndic a Madrid per a que el rei revocás el decret de retorn a l'escalafó de catedràtics dels dominics. Però el capità general Bucarelli impedí que aquell síndic - un trinitari - pogués sortir de Mallorca.

De totes maneres, la influència de Llull a la Universitat mallorquina fou molt important fins al darrer terç del segle XviII, fins als anys 1767-1772. Però les disputes entre lul listes i antilul listes no varen cessar. A partir de 1772, agafà força i s'imposà l'antilul lisme. Una reial ordre suprimí el nom de Lul liana de la Universitat, que passà a denominar-se exclusivament Universitat Literària de Mallorca. La Universitat, després de la expulsió dels jesuïtes el 1767 per Carles III, es va traslladar a l'edifici que aquells havien ocupat des de 1561 (Cassanyes 2012: 189-192). Per això s'organitzà una festa el 18 de maig de 1770 (Lladó 1973: 149-151). Després de la expulsió dels jesuïtes quedà suspesa la opinió suarista.

\section{La Universitat Literària de Mallorca}

A la segona meitat del segle XVIII, s'intentaren uniformitzar totes les universitats espanyoles mitjançant una reforma generalitzada dels seus plans d'estudis. El secretari Manuel de Roda encomanà a Gregori Mayans la redacció d'un pla d'estudis universitari, encàrrec que l'autor va concloure el 1767. Per posar en marxa el nou pla d'estudis a la Universitat de Mallorca, s'encarregaren informes a l'Ajuntament de Palma, a la Reial Audiència i a la pròpia Universitat, que una vegada impresos, el 1776 formaren un gruixat volum. L'informe de la Universitat que proposava mesures per millorar la qualitat dels estudis, va fer referència a la pobra dotació de les càtedres i a la escassa aplicació dels escolars. De 32 càtedres existents -14 de teologia, 5 de cànons i lleis, 5 de medicina, 5 de filosofia, 2 de geometria i 1 de retòrica- únicament 12 tenien dotació. S'afegí que algunes d'aquestes càtedres «se regentan por religiosos o sacerdotes seculares [que] tienen unos en el convento y otros en el titulo patrimonial asegurado su sustento».

El 1772, a un claustre celebrat el 3 de març, un catedràtic d'Instituta, Antoni Bisquerra, canonge tomista, manifestà que la Universitat no devia portar més temps el qualificatiu de Lul liana com a signe d'identitat, lo que fou aprovat. Per entendre el viratge en la denominació oficial de la Universitat mallorquina, hi ha que tenir en compte dos factors bàsics: la forta animadversió dels dominics cap a la figura de Ramon Llull i al lul lisme, i l'antijesuitisme de Carles III (Ramis 2011: 103). Tant els que eren llavors capità general com el bisbe de Mallorca en aquell moment formaven part d'una xarxa que cristal litzà en una majoria política antilul liana. A la expulsió dels jesuïtes i a la prohibició oficial d'ensenyament del suarisme, seguí el nomenament de juristes declarats 
antilul listes per oficis claus. A més, el nou bisbe de la diòcesi mallorquina a partir de 1772, Díaz de la Guerra, declarat antilul lista intervingué en aquesta matèria (Ramis 2011: 107). El 1775 s'intentà suprimir la festa que cada any celebrava la Universitat en honor de Ramon Llull. S'esborraren del calendari les festes dedicades a Ramon Llull. I el 1776 va ser prohibida per decret qualsevol manifestació pública de lul lisme (Ferrer 2001: 65-89). Els franciscans se posicionaren a favor del lul lisme i el seu provincial escrigué una carta en aquesta direcció a Carles III, sense cap èxit. A partir de llavors els dominics controlaren majoritàriament la Universitat. Díaz de la Guerra va fer observar la reial ordre de Carles III dictada el 1768 en la que preveia que l'ensenyament se fes en la llengua castellana «exhortamos a los catedràticos a que aquella enseñanza y explicación que ante la permitiamos en vuestro idioma Mallorquín, la hagan precisamente en lo sucesivo en llengua castellana».

A Mallorca el 1778 va ser creada una Societat Econòmica d'Amics del País. L'acord entre aquesta societat i la Universitat va promoure la creació de nous estudis com l'Acadèmia medico-pràctica de Mallorca, aprovada el 1788 per Carles III amb la finalitat d'implantar les pràctiques d'hospital i iniciar un banc de dades sobre malalties i sanitat a l'illa. L'Ajuntament de Palma completà el pla amb la erecció de l'Escola Mallorquina d'Anatomia i Cirurgia el 1786, que començà a impartir ensenyaments a partir de 1790 i va funcionar fins el 1824.

El canvi de denominació de la Universitat mallorquina no va ser motiu per a que estudiants de fora acudissin a ella per obtenir uns graus que passaven per ser més difícils a Universitats de la península. Per aquestes dades, va començar a fer-se patent que a la Universitat mallorquina era fàcil obtenir determinats graus i que estudiants de la península acudien a ella per poder graduarse. La sol licitud des de la Cort del número d'estudiants que s'havien graduat entre 1785 i 1788 demostra una presència important d'estudiants de la península, especialment catalans a les Facultats de Teologia i de Dret, a més de les altres. De teologia se concediren, en aquells tres anys, 106 graus: 36 per mallorquins i 70 per estudiants de la península, la major part -50 catalans-. De Cànons i Lleis, se donaren 36 graus: la meitat per mallorquins, 17 per catalans i 1 per un valencià (Lladó 1973: 140-141). A partir de la dècada de 1770, després de la clausura de la Universitat de Gandia, molts d'estudiants catalans fugien de la Universitat de Cervera i s'embarcaven cap a Mallorca per obtenir els graus que desitjaven (Amengual 2002: 917). Se notà a Mallorca un augment d'estudiants procedents de Catalunya. Segons el coetani testimoni del jurista Joaquim Fiol entre el setembre de 1782 i el febrer de 1788, vuitanta catalans se graduaren en teologia a la Universitat mallorquina (Pons, 1933: 310). La Universitat de Cervera es queixà per que els seus estudiants, a la mínima imposició, amenaçaven en graduar-se a Mallorca. Aquest assumpte va arribar al Consell de Castella i a la Cort. La Universitat mallorquina va rebre una missiva reial en la que el monarca l'advertia de que «no vol el rey que los graus se conferesquen ab la facilitat de que queda enterat el Consell». Sabem que entre 1771 i 1806, la Universitat mallorquina tingué 5.425 estudiants, lo que suposava un percentatge de 155 per any. 
A partir de finals del segle XVIII, s'impulsà l'estudi de disciplines com la legislació nacional espanyola i de les matemàtiques. De totes maneres la Universitat mallorquina va continuar amb el manteniment d'un caràcter marcadament religiós de la seva producció científica així com dels corrents teològics lul lista, tomista i escotista. El lul lista Antoni Pascual, catedràtic de filosofia, conciliador, que va viure a la Universitat els moments de domini del conservadorisme escolàstic i la introducció d'un moderat cientifisme renovador, es lamentà del predomini eclesiàstic dins la institució que considerà un perjudici per el progrés intel lectual. A aquesta època, la crítica situació de la Universitat mallorquina era un fet del qual els coetanis n'eren conscients. Dues eren les raons: la manca de finançament i la no adaptació al progrés científic i intel lectual del moment.

L'informe que la Societat Econòmica d'Amics del País va presentar com a resposta a un qüestionari sobre l'ensenyament a Mallorca manifestà una situació crítica de la Universitat a principis del segle XIX. La solució passava per la dotació de més càtedres i l'elaboració d'un nou pla d'estudis que seguís el de la Universitat de Salamanca. Jovellanos a la seva estada a Mallorca va fer una sèrie de consideracions respecte a la inutilitat de la institució universitària. L'intel lectual asturià va escriure que «toda su organización es absolutamente ajena de la que conviene a la nueva institución que Mallorca necessita».

El 1805 se plantejà la necessitat de reformar el pla d'estudis universitari. Aquest projecte de reforma ja va fer al lusió a que hi havia «pocos alumnos». Els plans d'estudis de principis del segle xix, de 1807, 1816 i 1824 ampliaren sobretot l'àrea de medicina, amb noves disciplines com la botànica, la higiene i la obstetrícia. El 1807, el rector de la Universitat considerava necessari uniformar la Universitat mallorquina amb les altres de la península, donada la crítica situació d'aquella institució. En els Informes Oficiales sobre Cortes enviats per les Balears a les Corts de Cadis, en el capítol sobre l'ensenyament, coincidiren en aconsellar incrementar l'estudi de la filosofia de l'experiència, fonamentada sobre les ciències físiques i les matemàtiques. Els informes de l'Ajuntament de Palma i de la Universitat feien referència a la necessitat de crear càtedres de ciències a la Facultat de Filosofia (Trías 1985: 242). Sol licitaren una càtedra per a cada una de les disciplines següents: matemàtiques, física experimental, química, història natural, botànica i cosmografia. Aquestes disciplines científiques serien el suport de la lògica, la metafísica i la filosofia moral. En l'àmbit del dret impulsaven la economia política i el dret natural, que fins aleshores havien estat postergats a causa de la seva vinculació amb l'Europa revolucionària. El 1820 es restablí el pla d'estudis de 1807, amb excepció de l'ensenyament de la Medicina. El pla d'estudis de 1824 ja no la va afectar perquè havia acabat la seva existència. Va romandre 129 anys a Mallorca. 


\section{Supressió de la Universitat Literària}

Quan el govern de Ferran VII demanà explicacions sobre els motius pels quals la majoria de les càtedres de la Universitat mallorquina estaven ocupades per interins, el rector va respondre que la institució es trobava «en los mayores apuros y misèria». El panorama no era gens afalagador. La precarietat financera de la institució va ser una de les seves característiques des del principi fins a la fi. No era factible la vinguda de figures de prestigi que renovessin el nivell acadèmic de la Universitat. La institució estava condemnada a la mediocritat. Tampoc progressava el número d'alumnes.

L’11 de febrer de 1830 se rebé a Palma una ordre de la Inspección de la Instrucción Pública dictada el 28 de desembre anterior que ordenava que les Universitats de Canàries i Mallorca quedessin incorporades als seus respectius Seminaris Conciliars (Lladó 1973: 329-331). A partir de llavors existí una pugna entre els poders locals per controlar el Seminari Conciliar. A Mallorca funcionaren dos centres d'ensenyament superior amb el nom de Seminari. Fins a llavors els seminaristes havien assistit a les aules de la Universitat, on cursaven filosofia i teologia. El Seminari funcionava únicament com a col legi major, com a residència dels seminaristes. Els òrgans directius de la Universitat intentaren canviar-li el nom pel de Seminari Conciliar de Mallorca, sense canviar l'estructura de l'antiga institució universitària, lo que topà amb l'oposició del bisbe que es considerà amb el dret exclusiu de controlar i dirigir el Seminari. Davant la impossibilitat d'arribar a un acord, al final de 1830, començaren a funcionar a Mallorca, dos Seminaris, l'un com a continuació de la Universitat -que matriculava els seus alumnes a la Universitat de Cervera- i l'altre instituït pel bisbe (Fullana 1995, pp. 119-120).

La Universitat havia deixat de funcionar a causa del caràcter poc pràctic i excessivament teòric del seu ensenyament i la indotació de càtedres. Els comissionats pel rector i el claustre de professors proposaren un pla per vincular les càtedres a canongies i dignitats eclesiàstiques, a més de continuar amb el sistema de patronat que mantenien els ordes religiosos. Era un projecte per donar continuïtat a la Universitat. Això no fou acceptat pel bisbe de Mallorca. Durant dos cursos -entre 1830 i 1832 s'intentà mantenir l'estructura universitària tradicional. Aquest centre amb el nom de Seminari era sostingut per religiosos, a excepció dels jesuites que havien passat a col laborar amb el bisbe. Amb motiu de l'exclaustració dels religiosos, els sistema universitari tradicional de l'illa desaparegué. L'existència de dos centres docents amb pretensió universitària, com eren els dos Seminaris, posà de manifest la manca d'homogeneïtat del clergat mallorquí, ja que eren clergues i religiosos d'una part i de l'altra el principals interessats a portar a terme iniciatives diverses.

La Universitat va ser restaurada l'octubre de 1840, amb el nom d'Universitat Literària Balear. La iniciativa partí del quadre docent de l'antiga Universitat. El seu principal impulsor fou Miquel Moragues Barceló, un eclesiàstic liberal. Tenia el suport de l'Ajuntament de Palma i de la Diputació. Era un dels fruits més immediats del progressisme local. Havia de tenir quatre facultats: teologia, 
dret civil i canònic, medicina i cirurgia i filosofia. El seu objectiu era modernitzar l'ensenyament amb estudis de llengües modernes com l'anglès i el francès, de lògica, de matemàtiques pures, i de ciències naturals, socials i morals. També es preveia la restauració dels estudis de medicina i cirurgia. Però la seva vida va ser efímera. L'agost de 1842 se suprimí definitivament aquesta Universitat. Entre les causes del tancament es poden citar l'escàs èxit en la matriculació, l'actitud de l'església mallorquina contra el sistema de control que podia exercir el progressisme liberal cap a la institució eclesiàstica, i l'estructura envellida de la universitat, tot i que es pretenia una relativa modernització. A partir de llavors tots els estudiants de les Illes Balears que volien cursar estudis superiors, s'havien de desplaçar a la península. No hi va tornar haver estudis universitaris a Mallorca fins més de cent anys després.

\section{Cap a la Universitat de les Illes Balears}

Va ser a la segona meitat del segle xx, el 1951, quan es reconstruí i refundà l'antic Estudi General. El 1959 es creà la Càtedra Ramon Llull. El 1967 s'inicià el funcionament d'una Secció Delegada de la Facultat de Filosofia i Lletres de la Universitat de Barcelona. El 1972 se creà la Facultat de Ciències depenent de la Universitat Autònoma de Barcelona. La Secció Delegada de la Facultat de Filosofia i Lletres de la Universitat de Barcelona fou elevada a Facultat pròpia el 1973. En aquella mateixa època començà a funcionar la Facultat de Dret depenent de l'Autònoma de Barcelona. Totes les Facultats dependents de les Universitats barcelonines, més dues Escoles Universitàries -de Formació del Professorat i d'Estudis Empresarials-, es fusionaren en la nova Universitat de Palma, creada el 1978, que ja té més de quaranta anys. El 1985 s'aprovaren els seus estatut -que foren reformats el 1989- i s'adoptà la denominació -que és l'actual- de Universitat de les Illes Balears. Des de 1996 funcionen extensions de la Universitat a les altres illes, Eivissa i Menorca. El 1996 les competències sobre la Universitat foren transferides per l'Estat a la Comunitat Autònoma de les Illes Balears. Ha ampliat estudis i disposa de Facultat de Medicina. 


\section{Bibliografia}

Amengual i Batle, J. (2002) «La preilustración en los medios eclesiásticos de Mallorca (ss. XVII-XVIII)» Hispania, 212, pp. 907-956.

Barceló, Ma \& Urgell, R. (2002) «La Universitat de Mallorca: origen i evolució fins al segle XVIII» a Busqueta, J.J. i Pemán, J. Les Universitats de la Corona d'Aragó, abir i avui. Estudis històrics, Universitat de Lleida-Pòrtic, pp. 157-192.

Bestard Nadal, B. (2008) «La facultat de Medicina de la Reial i Pontifícia Universitat Literària del Regne de Mallorca» a Bonner, A. i Bujosa, F. (dirs.) Història de la Ciència a les Illes Balaers, 3, pp. 149-161.

Cassanyes Roig, A. (2011) «Les disputes en el Col legi de Medicina de la Universitat Literària de Mallorca (1696-1699)», Bolletí de la Societat Arqueologica Lul liana, 67, pp. 193-204.

- (2012) «El Col legi de Monti-Sion després de l'expó dels Jesuïtes (1767-1772)» Bolletí de la Societat Arqueològica Lul liana, 68, pp. 185-199.

Cassanyes Roig, A \& Ramis Barceló, R. (2012) «El atentado antiluliano de 1699 en el marco ideológico de la Universidad de Mallorca», Memòries de la Reial Acadèmica Mallorquina d'Estudis Genealògics, 22, pp. 141-165.

(2014) «Los grados de artes y filosofía en la Universidad Luliana y Literaria de Mallorca (1692-1823)», Analecta sacra tarraconensia, 87, pp. 271-294.

- (2014) «Los grados en teologia escotista en la Universidad Luliana y Literaria de Mallorca (1692-1823)», Archivo Ibero-Americano, no 277-278, pp. 7-51.

—_. (2015) «Los grados en Teología luliana en la Universidad de Mallorca (1692-1824)», Bolletí de la Societat Arqueologica Lul liana, 71, pp. 93-127.

Ensenyat Pujol, G. «Les institucions d'alta cultura: de l'Estudi General Lul lià a la Universitat Literària» a Bonner, A. i Bujosa, F. (dirs.) Història de la Ciència a les Illes Balaers, 2, pp. 17-33.

Ferrer Flórez, M. «Culte a Ramon Llull: discòrdies i controvèrsies», Bolletí de la Societat Arqueològica Lul liana, 41, pp. 65-89.

Fullana Puigserver, P. (1995) «La Reial i Pontifícia Universitat Literària de Mallorca. En torn del fet de la supressió (1829-1835)», Afers, 20, pp. 117-128.

Juan Vidal, J. (2019) Gobernar un reino. Mallorca en tiempos de Carlos II, Palma, El Tall.

Lladó y Ferragut, J. (1973) Historia del Estudio General Luliano y de la Real y Pontificia Universidad Literaria de Mallorca, Palma de Mallorca, Ediciones Cort.

Miralles Sbert, J. «Sobre la concesión a la Universidad de Mallorca de la facultad de conferir grados», Bolletí de la Societat Arqueològica Lul tiana, VII, pp. 187-188. 
Pérez Martínez, L. (1985) «Un nuevo texto acerca de un atentado contra el culto de Ramon Llull», Bolletí de la Societat Arqueologica Lul liana, 41, pp. 333-359.

(1989) «Un capitulo sobre el lulismo mallorquín: el Te Deum de 1750», Bolletí de la Societat Arqueologica Lul liana, 45, pp. 333-341.

Piña Homs, R. (2015) Historia de la Universidad en Mallorca: grandezas y miserias de una élite intelectual: siglos XV-XX, Palma, Lleonard Muntaner.

Planas Rosselló, A. (2011) «La enseñanza del derecho y la formación de los juristas durante la época del Estudio General Luliano, 1483-1692», Cuadernos del Instituto Antonio de Nebrija, 14-1, pp. 75-91.

Planas Rosselló, A. \& Ramis Barceló, R. (2011) La Facultad de Leyes y Cánones de la Universidad Luliana y Literaria de Mallorca, Madrid, Carlos III.

Pons, A. (1933) Dietari del Dr. Fiol. Memòries de D. Joaquim Fiol de Mallorca, Doctor en Drets, que compren de l'any 1782 fins en 1788, Ciutat de Mallorca, Publicacions de la Societat Arqueològica Luliana.

——. (1975) «Beatriz de Pinós i l’Estudi General», Studia Luliana, 19, pp. 81-105.

Ramis Barceló, R. (2010) «Fray Agustín Pipia y la Universidad Luliana y Literaria de Mallorca», Archivum fratrum predicatorum, 80, pp. 177-199.

- (2011) «En torno a la supresión del connotativo "Luliana" de la denominación histórica de la Universidad de Mallorca», Memòries de la Reial Acadèmica Mallorquina d'Estudis Genealògics, 21, pp. 103-119.

—_. (2014) «Las cátedras lulianas de la Universidad de Mallorca», Bolletí de la Societat Arqueològica Lul liana, 70, pp. 185-205.

Santamaría Arández, A. (1976) «La donación proluliana de Beatriu de Pinós», Bolletí de la Societat Arqueologica Lul liana, 25, pp. 37-140.

—_. (1979) Proceso de institucionalización de la Universidad Luliana de Mallorca, Universidad de Palma de Mallorca.

. (1983) La promoción universitaria en Mallorca. Época de Fernando el Católico, Universidad de Palma de Mallorca. 